\title{
Thallium Trinitrate Mediated Ring Contraction of cis-2-Decalones
}

\author{
Helena M. C. Ferraz " and Luiz F. Silva Jr. \\ Instituto de Química, Universidade de São Paulo, CP 26077, 05513-970, São Paulo - SP, Brazil
}

\begin{abstract}
A reação de uma série de cis-2-decalonas com $\mathrm{TTN}$ em $\mathrm{CH}_{2} \mathrm{Cl}_{2}$ à temperatura ambiente foi investigada. As reações de contração de anel ocorreram com bons rendimentos, porém a regio- e a diastereosseletividade foram baixas. A influência de grupos alquílicos na regioquímica da reação depende da sua posição no anel decalínico.
\end{abstract}

The reaction of some cis-2-decalones with TTN in $\mathrm{CH}_{2} \mathrm{Cl}_{2}$ at room temperature was investigated. The ring contraction reactions occurred in good yields, however the regio- and diastereoselectivity were low. The effect of the alkyl groups in the regiochemistry of the reaction depends on their position at the decalone ring system.

Keywords: thallium trinitrate, oxidation, hydrindanes, ring contraction, decalones

Cis-fused hydrindanes are an important moiety present in several natural products, such as bakkenolide- $\mathrm{A}^{1}$ and thapsanol ${ }^{2}$. In the course of the synthesis of these challenging targets, we sought for an efficient method to promote the ring contraction of cis-2-decalones.

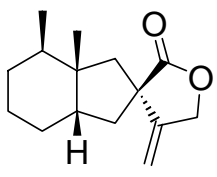

Bakkenolide-A

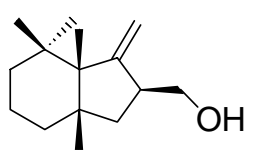

Thapsanol
Thallium(III) salts have been successfully used in the ring contraction of trans-2-decalones ${ }^{3}$, as well as steroidal ketones ${ }^{4,5}$, although some exceptions have also been reported $^{4,6}$. However, only two papers describing the reactions of cis-2-decalones or related compounds with thallium(III) salts have been published ${ }^{7,8}$. In both of them, a single ring contraction product was obtained in low yield, as exemplified in Scheme 1. We anticipated that the low yield could be overcome using different experimental conditions for promoting this ring contraction ${ }^{3,9-11}$ and, consequently, an efficient methodology for constructing cishydrindanes could be established.

The first substrate studied was the decalone 1 (see Table 1), which was treated with thallium trinitrate (TTN) in $\mathrm{CH}_{2} \mathrm{Cl}_{2}$ at room temperature. Although the yield was indeed

\footnotetext{
*e-mail: hmferraz@iq.usp.br
}

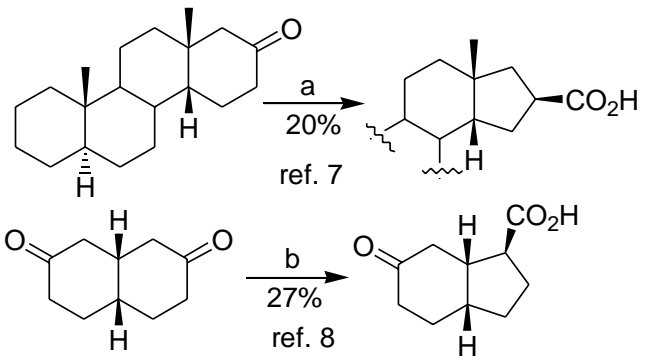

(a) TTA, AcOH; (b) TTN, AcOH

Scheme 1.

improved under this condition, the reaction occurred with low regio- and diastereoselectivity, being observed three diastereomers of the four possibles (Table 1, entry 1). Two aspects can be invoked to explain this low selectivity. First, the formation of both enol forms of the ketone $\mathbf{1}^{12}$, which is responsible for the low regioselectivity. The $\Delta^{1,2}$ enol leads to the hydrindanes substituted at $\mathrm{C} 1$ position, whereas the $\Delta^{2,3}$ furnishes the carboxyl group at the $\mathrm{C} 2$ position (Figure 1). In 1988, Huffman and Balke ${ }^{13}$ showed that the decalone 1 gives a slightly excess of the $\Delta^{2,3}$ trimethylsilyl enol ether, under thermodynamic conditions (TMSI/ $\left(\mathrm{Me}_{2} \mathrm{Si}\right)_{2} \mathrm{NH} /$ $\mathrm{CH}_{2} \mathrm{Cl}_{2}$ ), which agrees with our result. The second aspect concerns the flexibility of the cis-fused system, which allows the trans-diaxial addition from both faces, thus explaining the low diastereoselectivity (Figure 1). We have no explanation for the fact that only three of the four possible diastereomers have been formed in the ring contraction reaction. 
Table 1. Reaction of cis-2-decalones with TTN in $\mathrm{CH}_{2} \mathrm{Cl}_{2}$ at room temperature.

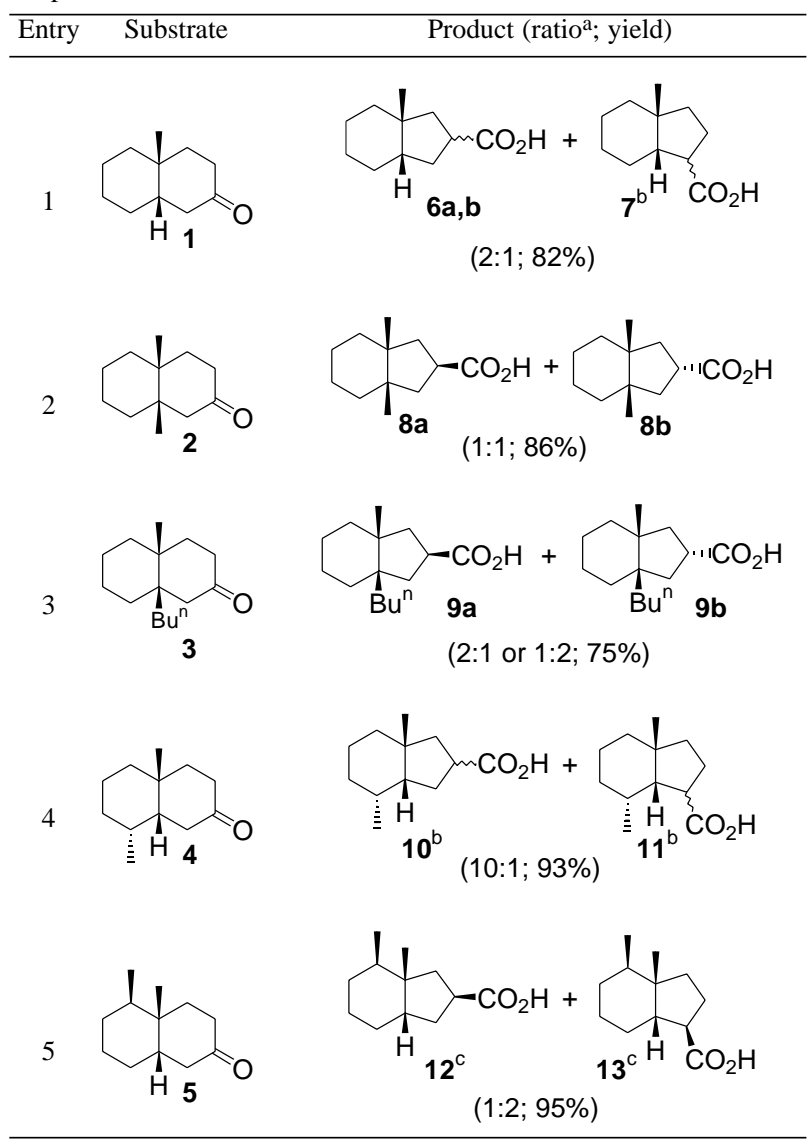

${ }^{a}$ The ratio was determined by ${ }^{13} \mathrm{C}-\mathrm{NMR}$ (Inverse Gated Decoupling), except for 12:13, which was estimated by GC and ${ }^{1} \mathrm{H}-\mathrm{NMR}$ analysis; ${ }^{b}$ Single stereoisomer. Relative configuration not determined; ${ }^{c}$ Relative configuration determined by comparison with literature ${ }^{14}$.
Under similar reaction conditions, the 9,10-dialkyldecalones $\mathbf{2}$ and $\mathbf{3}$ led to the diastereomeric ring contraction products $\mathbf{8 a} / \mathbf{8 b}$ and $\mathbf{9 a} / \mathbf{9 b}$, respectively (Entries 2 and 3). These results suggest that only the $\Delta^{2,3}$ enol was formed from the substrates $\mathbf{2}$ and $\mathbf{3}$. Therefore, the presence of two alkyl groups at the ring junction increased the regioselectivity, when compared to the substrate bearing an hydrogen at the same position.

The introduction of a methyl group at $\mathrm{C} 8$ position shows pronounced effect not only in the regio-, but also in the diastereoselectivity, as observed in the reaction of the decalone 4 with TTN. This reaction led to the formation of a single diastereoisomer of each regioisomeric acids $\mathbf{1 0}$ and 11, in a 10:1 ratio (Entry 4).

On the other hand, in the ring contraction of the decalone $\mathbf{5}$, which bears a methyl group at $\mathrm{C} 5$, an inversion in the regiochemistry of the reaction was observed, when compared to the other cis-fused substrates studied. In this case, the $\Delta^{1,2}$ enol form was the preferable pathway of the reaction (Entry 5). The ring contraction of the cis-decalone 5 promoted by $\mathrm{SeO}_{2}$ was investigated by $\mathrm{Da} \mathrm{Silva}^{14}$, in 1984. Using this oxidant, the acids $\mathbf{1 2}$ and $\mathbf{1 3}$ were obtained in a 2:3 ratio, respectively. It is worth noting that the result of the ring contraction of the decalone 5 was critical in our initial plan to the synthesis of bakkenolide-A. Due to the observed regioselectivity, a new route is being planned to achieve the desired carboxylic acid $\mathbf{1 2}$.

It is interesting to note that the 2-substituted hydrindanes 6, 10 and 12 can be distinguished from the corresponding 1-substituted 7, 11 and 13, respectively, by ${ }^{13} \mathrm{C}$ NMR.

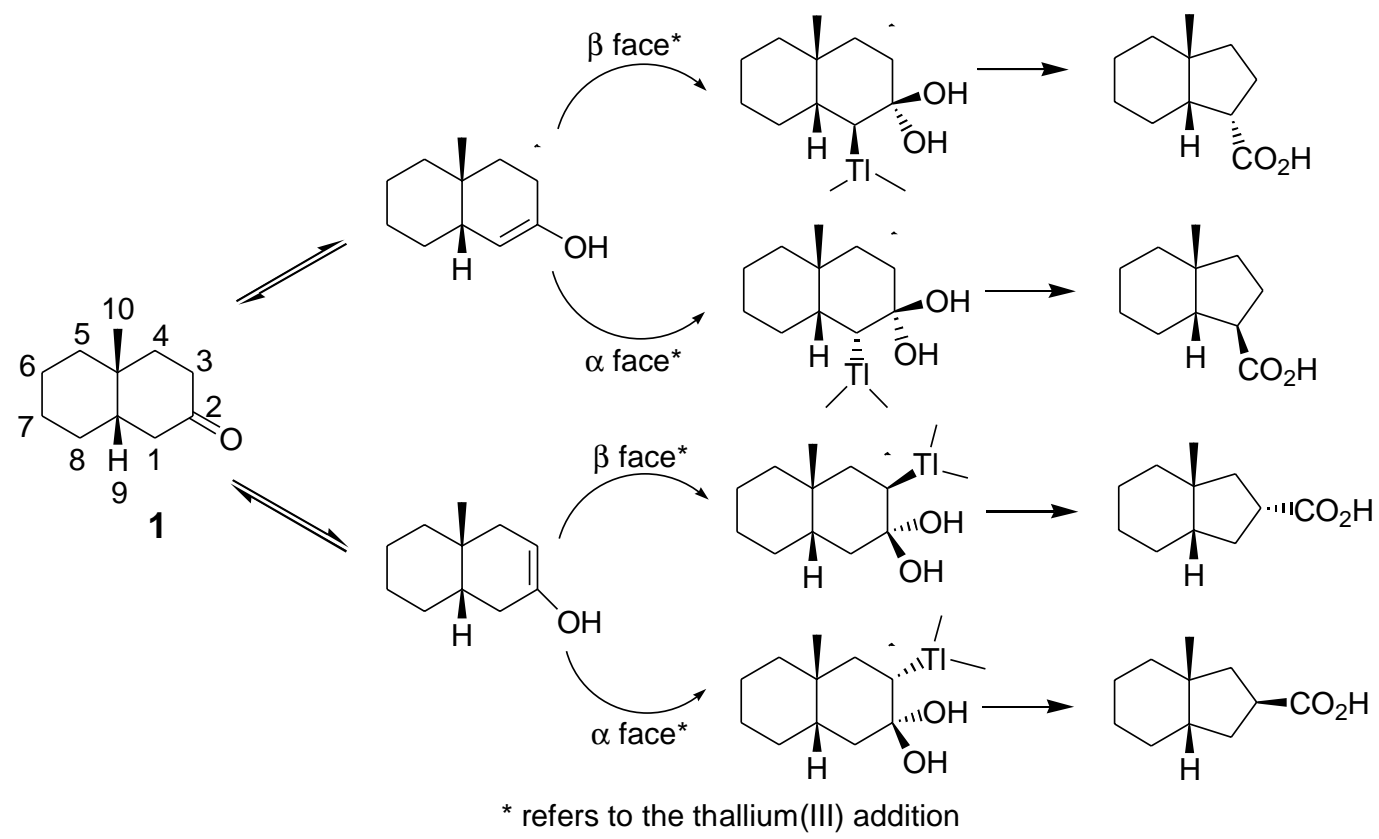

Figure 1. Possible ring contraction products from 1. 
The carbon attached to the carboxyl group in 6, 10 and $\mathbf{1 2}$ is shielded by $c a .5 \delta$ when compared to the 1 -substituted hydrindanes. Thus, it was possible to determine their ratio by inverse gated decoupling.

In contrast to the behavior of the cis-decalones 1, 4 and $\mathbf{5}$, the reaction of the corresponding trans-2-decalones, under similar conditions, has furnished a single ring contraction product, as exemplified for trans-10-methyl2-decalone in Scheme $2^{3,15}$.

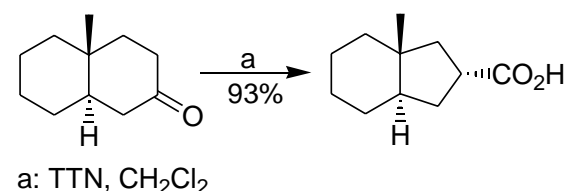

Scheme 2.

In summary, we showed that cis-2-decalones furnish ring contraction products in good yields, although in low regio- and diastereoselectivities (except for the substrate 4). We also revealed that the effect of the alkyl groups in the ring contraction depends on their position in the decalone ring system, in a non-straightforward manner. Changing the alkyl group from methyl to $n$-butyl in the ring junction slightly increased the diastereoselectivity of the reaction.

\section{Experimental}

Caution! Thallium(III) salts are toxic and must be handled with care.

The decalones $\mathbf{1}^{16}, \mathbf{4}^{17}$ and $\mathbf{5}^{14}$ were prepared by hydrogenation ( 1 atm $\left.\mathrm{H}_{2}, 10 \% \mathrm{Pd} / \mathrm{C}, \mathrm{MeOH} / \mathrm{HCl}\right)$ of the corresponding octalones ${ }^{18-21}$. 2,3-Dimethylcyclohexanone, used in preparation of $\mathbf{5}$, was obtained by Jones oxidation of the 2,3-dimethylcyclohexanol. The decalones $2^{16}$ and $\mathbf{3}^{22}$ were prepared by cuprate addition ${ }^{23,24}$, using the corresponding octalone ${ }^{18}$ as starting material. Thallium trinitrate was purchased from Aldrich and was used as received. ${ }^{1} \mathrm{H}$ and ${ }^{13} \mathrm{C}$ NMR spectra were recorded at 300 and $75 \mathrm{MHz}$, respectively, on a Bruker DPX-300 spectrometer. The reactions were followed by gas chromatography using a HP-6890 series II.

General procedure for the reaction of cis-2-decalones with TTN

A typical procedure is described for the reaction of the cis-2-decalone $\mathbf{1}$ with TTN. To a stirred solution of $\mathbf{1}$ $(0.048 \mathrm{~g}, 0.29 \mathrm{mmol})$ in $\mathrm{CH}_{2} \mathrm{Cl}_{2}(5 \mathrm{~mL})$, was added TTN. $3 \mathrm{H}_{2} \mathrm{O}(0.28 \mathrm{~g}, 0.64 \mathrm{mmol})$. The mixture was stirred at room temperature for 24 hours and then filtered through Celite ${ }^{\circledR}$. The filtrate was washed with brine and dried over anhydrous magnesium sulfate. The solvent was concentrated under reduced pressure to give $\mathbf{6}$ and 7 $(0.043 \mathrm{~g}, 0.24 \mathrm{mmol}, 82 \%)$ in a $2: 1$ ratio, respectively, as a pale yellow oil; $v_{\max } / \mathrm{cm}^{-1} 2930,2862,1702$ (film); ${ }^{1} \mathrm{H}$ NMR (300 MHz, $\left.\mathrm{CDCl}_{3}\right) \delta 0.98,1.03$ and 1.04 (s, 3H), 1.15-2.09 (m, 13H), 2.90-2.99 (m, 1H); ${ }^{13} \mathrm{C}$ NMR $(75$ $\left.\mathrm{MHz}, \mathrm{CDCl}_{3}\right) \delta 20.5,20.7,21.3,21.8,21.9,22.1,22.7$, 23.3, 24.5, 25.0, 25.3, 26.5, 26.6, 32.4, 32.7, 33.0, 33.3, 34.0, 39.8, 40.2, 40.4, 40.8, 40.9, 41.0, 43.2, 43.8, 44.2, $44.9,45.2,49.0,183.3,183.5,183.7 ; \mathrm{m} / \mathrm{z}$ major: $182\left(\mathrm{M}^{+}\right.$, 19\%), 167 (18), 164 (12), 149 (19), 137 (19), 110 (41), 95 (92), 81 (100), 67 (76), 55 (59); minor: $182\left(\mathrm{M}^{+}, 3 \%\right)$, 167 (2), 164 (2), 149 (6), 137 (5), 110 (100), 95 (38), 81 (59), 67 (38), 55 (31).

\section{Reaction of the cis-2-decalone 2 with TTN}

The reaction was performed following the general procedure, using 2 (0.038 g, $0.21 \mathrm{mmol}), \mathrm{CH}_{2} \mathrm{Cl}_{2}(4 \mathrm{~mL})$ and TTN. $3 \mathrm{H}_{2} \mathrm{O}(0.10 \mathrm{~g}, 0.32 \mathrm{mmol})$, and stirring for $48 \mathrm{~h}$. The acid $\mathbf{8}$ was obtained in a 1:1 mixture of diastereomers $(0.036 \mathrm{~g}, 0.18 \mathrm{mmol}, 85 \%)$ as viscous pale yellow oil; $v_{\max } / \mathrm{cm}^{-1} 2958,2931,1694$ (film); ${ }^{1} \mathrm{H}$ NMR (300 MHz, $\left.\mathrm{CDCl}_{3}\right) \delta 0.87(\mathrm{~s}, 3 \mathrm{H}), 0.90(\mathrm{~s}, 3 \mathrm{H}), 1.21-2.15(\mathrm{~m}, 12 \mathrm{H})$, 2.90-3.04 (m, 1H); $\left.{ }^{13} \mathrm{C} \mathrm{NMR} \mathrm{(75} \mathrm{MHz,} \mathrm{CDCl}_{3}\right) \delta 22.2$, 22.3, 22.8, 23.3, 34.3, 34.5, 38.6, 38.9, 40.8, 41.0, 43.2, $43.3,183.2$.

\section{Reaction of the cis-2-decalone 3 with TTN}

The reaction was performed following the general procedure, using $3(0.279 \mathrm{~g}, 1.26 \mathrm{mmol}), \mathrm{CH}_{2} \mathrm{Cl}_{2}(20 \mathrm{~mL})$ and TTN. $3 \mathrm{H}_{2} \mathrm{O}(0.62 \mathrm{~g}, 1.4 \mathrm{mmol})$, and stirring for $48 \mathrm{~h}$. The acid 9 was obtained in a 2:1 mixture of diastereomers $(0.224 \mathrm{~g}, 0.94 \mathrm{mmol}, 75 \%)$ as pale yellow oil; $v_{\max } / \mathrm{cm}^{-1}$ 2933, 2861, 1703 (film); ${ }^{1} \mathrm{H}$ NMR (300 MHz, $\left.\mathrm{CDCl}_{3}\right) \delta$ 0.85-0.92 (m, 6H), 1.07-1.41 (m, 13H), 1.60-1.74 (m, 2H), $1.85-1.93(\mathrm{~m}, 2 \mathrm{H}), 2.12-2.26(\mathrm{~m}, 1 \mathrm{H}), 2.92-3.03(\mathrm{~m}, 1 \mathrm{H})$; ${ }^{13} \mathrm{C} \mathrm{NMR}\left(75 \mathrm{MHz}, \mathrm{CDCl}_{3}\right) \delta 21.8,22.0,22.1,23.4,23.8$, 23.8, 24.2, 27.1, 29.5, 29.9, 33.0, 33.9, 34.0, 38.4, 38.5, 38.8, 39.0, 39.7, 40.3, 44.1, 44.4, 45.6, 46.0, 183.4; m/z $238\left(\mathrm{M}^{+}\right.$, $0.19 \%), 181$ (45), 163 (67), 135 (100), 121 (4), 107 (16), 93 (24), 79 (26), 67 (29), 55 (39).

\section{Reaction of the cis-2-decalone 4 with TTN}

The reaction was performed following the general procedure, using 4 (0.486 g, $2.70 \mathrm{mmol}), \mathrm{CH}_{2} \mathrm{Cl}_{2}(35 \mathrm{~mL})$ and TTN. $3 \mathrm{H}_{2} \mathrm{O}(2.4 \mathrm{~g}, 5.4 \mathrm{mmol})$, and stirring for $24 \mathrm{~h}$. The acids $\mathbf{1 0}$ and $\mathbf{1 1}$ were obtained in a 10:1 mixture of diastereomers $(0.494 \mathrm{~g}, 2.52 \mathrm{mmol}, 93 \%)$ as pale yellow 
oil; $v_{\max } / \mathrm{cm}^{-1} 2960,1706,1631$ (film); ${ }^{1} \mathrm{H}$ NMR (300 $\left.\mathrm{MHz} \mathrm{CDCl}_{3}\right) \delta 0.85(\mathrm{~d}, \mathrm{~J} 6.7 \mathrm{~Hz}, 3 \mathrm{H}), 1.04(\mathrm{~s}, 3 \mathrm{H}), 0.76-$ $2.49(\mathrm{~m}, 12 \mathrm{H}), 2.87-2.98(\mathrm{~m}, 1 \mathrm{H}) ;{ }^{13} \mathrm{C}$ NMR $(75 \mathrm{MHz}$, $\mathrm{CDCl}_{3}$ ) major: $\delta$ 20.5, 22.2, 23.8, 27.6, 28.1, 29.1, 31.8, 39.2, 41.8, 45.8, 49.7, 183.9; minor: $\delta$ 20.5, 32.0, 32.9, $38.7,39.0,41.0,41.3,42.3,47.2,49.3,53.7,183.0 ; \mathrm{m} / \mathrm{z}$ $196\left(\mathrm{M}^{+}, 6 \%\right), 178$ (4), 163 (6), 153 (11), 135 (18), 124 (59), 109 (100), 95 (51), 81 (67), 67 (49), 55 (45).

\section{Reaction of the cis-2-decalone 5 with TTN}

The reaction was performed following the general procedure, using 5 (0.656 g, $3.64 \mathrm{mmol}), \mathrm{CH}_{2} \mathrm{Cl}_{2}(50 \mathrm{~mL})$ and TTN. $3 \mathrm{H}_{2} \mathrm{O}(3.2 \mathrm{~g}, 7.3 \mathrm{mmol})$, and stirring for $24 \mathrm{~h}$. The acids $\mathbf{1 2}$ and $\mathbf{1 3}$ were obtained in a 1:2 mixture of diastereomers $(0.676 \mathrm{~g}, 3.45 \mathrm{mmol}, 95 \%)$ as pale yellow oil; $v_{\max } / \mathrm{cm}^{-1} 2958,1704,1638$ (film); ${ }^{1} \mathrm{H}$ NMR (300 $\left.\mathrm{MHz}, \mathrm{CDCl}_{3}\right) \delta$ 0.78-0.96 (m, 6H), 1.01-2.17 (m, 12H), 2.86-2.99 (m, 1H); $\left.{ }^{13} \mathrm{C} \mathrm{NMR} \mathrm{(75} \mathrm{MHz,} \mathrm{CDCl}_{3}\right) \delta 16.7$, 19.0, 19.2, 21.0, 21.2, 23.1, 23.8, 25.8, 30.5, 31.3, 32.6, 33.0, 37.5, 39.7, 39.9, 42.6, 44.3, 44.6, 44.8, 45.9, 46.0, 51.4, 183.7, 184.1; $\mathrm{m} / \mathrm{z}$ major: $196\left(\mathrm{M}^{+}, 18 \%\right), 181(8)$, 178 (8), 163 (5), 151 (64), 135 (14), 126 (14), 109 (81), 95 (80), 81 (100), 67 (50), 55 (56); minor: $196\left(\mathrm{M}^{+}, 36 \%\right)$, 181 (4), 178 (4), 163 (3), 151 (31), 135 (11), 126 (22), 109 (65), 95 (84), 81 (100), 67 (55), 55 (57).

\section{Acknowledgment}

The authors wish thank Prof. Dr. Ivan P. A. Campos for his help in some NMR experiments. We are also grateful for the financial support provided by FAPESP, CNPq and CAPES.

\section{References}

1. Abe, N.; Onoda, R.; Shirahata, K.; Kato, T.; Woods, M. C.; Kitahara, Y. Tetrahedron Lett. 1968, 369.

2. Smitt, U. W.; Cornet, C.; Norup, E.; Christensen, S. B. Phytochemistry 1990, 29, 873.

3. Ferraz, H. M. C.; Silva Jr., L. F. J. Org. Chem. 1998, 63, 1716 .
4. Romeo, A.; Ortar, G. Tetrahedron 1972, 28, 5337.

5. Maione, A. M.; Romeo, A.; Cerrini, S.; Fedeli, W.; Mazza, F. Tetrahedron 1981, 37, 1407.

6. Ortar, G.; Romeo, A. J. Chem. Soc., Perkin Trans. 1 1976, 111.

7. Auclair, J. -P.; Gramain, J. -C. J. Chem. Soc., Perkin Trans. 1 1988, 23.

8. Bird, C. W.; Cooper, R. Org. Prep. Proced. Int. 1993, 25, 237.

9. Ferraz, H. M. C.; Silva Jr., L. F. Tetrahedron Lett. 1997, 38, 1899.

10. For a review concerning thallium(III) chemistry, see: Ferraz, H. M. C.; Vieira, T. O.; Silva Jr., L. F. Synthesis 1999, 2001.

11. For a review concerning thallium(III) mediated ring contraction, see: Ferraz, H. M. C.; Silva Jr., L. F. Quim. Nova 2000, 23, 216.

12. Mundy, B. P. J. Chem. Ed. 1972, 49, 91.

13. Huffman, J. W.; Balke, W. H. J. Org. Chem. 1988, 53,3828 .

14. Da Silva, G. V. J. PhD Thesis, University of Sao Paulo, 1984.

15. For a discussion concerning thallium(III) mediated ring contraction of trans-2-decalones, see reference 3.

16. Gramain, J. C.; Quirion, J. C. Magn. Res. Chem. 1986, 24, 938.

17. Caine, D.; Smith, J. T. L. J. Org. Chem. 1978, 43, 755 .

18. Heathcock, C. H.; Ellis, J. E.; McMurry, J. E.; Coppolino, A. Tetrahedron Lett. 1971, 4995.

19. Still, W. C.; VanMiddlesworth, F. L. J. Org. Chem. 1977, 42, 1258.

20. Marshall, J. A.; Schaeffer, D. J. J. Org. Chem. 1965, 30, 3642.

21. Zoretic, P. A.; Yu, B. C.; Caspar, M. L. Synth. Commun. 1989, 19, 1859.

22. Kingsbury, C. L.; Smith, R. A. J. J. Org. Chem. 1997, 62, 4629.

23. Lipshutz, B. H.; Wilhelm, R. S.; Kozlowski, J. A. Tetrahedron Lett. 1982, 23, 3755.

24. Lipshutz, B. H.; Wilhelm, R. S.; Kozlowski, J. A. J. Org. Chem. 1984, 49, 3938.

Received: September 21, 2000

Published on the web: May 21, 2001

FAPESP helped in meeting the publication costs of this article. 